mgr Monika Szewczyk*

\title{
ODPOWIEDZIALNY MARKETING, CZYLI MARKETING SPOLECZNIE ZAANGAŻOWANY
}

\author{
RESPONSIBLE MARKETING - CAUSE RELATED MARKETING
}

\begin{abstract}
Marketing describes the social processes involving the free exchange of goods and services, it is also called the art of selling products. First of all, it is a process based on the planning and execution of ideas, setting prices, as well as the promotion and distribution of ideas, goods and services. The growing importance of the concept of sustainable development and corporate social responsibility makes that the marketing strategies of companies are beginning to be based on responsibility and honesty. That form of marketing leads to the implementation of cause related marketing. It involves combining economic objectives of the company with social objectives. There are many positive examples of such actions and activities led by companies. Unfortunately, there are also controversial cases, often arousing distaste among consumers. They are caused by misunderstanding of ideas and the desire to improve the company's image and catch the attention to the existence of the brand on the market in an aggressive way. The aim of the study is to present the application of cause related marketing with the principles of corporate social responsibility, as well as the controversy appearing in this area.
\end{abstract}

Keywords: marketing, cause related marketing (CRM), corporate social responsibility (CSR)

JEL classification: M20, M14, M31

\section{Wstęp}

W czasach globalizacji i rosnącego postępu technologicznego, które prowadzą do szybkiego rozprzestrzeniania się informacji oraz rozszerzania się działalności gospodarczej na inne państwa, mamy do czynienia z rosnącą konkurencją między firmami, a w szczególności między dużymi korporacjami, rywalizującymi na poziomie międzynarodowym. Przedsiębiorstwa różnej wielkości i na różnym poziomie konkurują, by osiągnąć jak najlepsze wyniki finansowe, które zapewnią

* Doktorantka - Katedra Gospodarki Światowej i Integracji Europejskiej, Wydział Ekonomiczno-Socjologiczny, Uniwersytet Łódzki; szewczyk.monikaa@gmail.com. 
im istnienie i możliwość kontynuacji działalności oraz dobrą pozycję na rynku. By utrzymać lub osiągnąć pożądaną pozycję na rynku, firma stosuje zabiegi mające na celu przekonanie klienta do swoich usług i produktów, nawiązuje z nim relacje, a następnie stara się ją utrzymać na stałe, zapewniając obustronne korzyści. Takie czynności i działania skoncentrowane na konsumencie noszą nazwę marketingu.

W perspektywie zmian klimatycznych i zwiększania się świadomości społeczeństwa wzrasta także potrzeba dbałości o środowisko naturalne i człowieka. Szczególna rola w tym zadaniu przypada przedsiębiorstwom, które w intensywny sposób oddziałują na otoczenie. Poprzez swoją działalność wpływają na konsumenta, korzystają z zasobów środowiska przyrodniczego oraz przyczyniają się do rozwoju gospodarczego. Planując swoje strategie, firmy powinny brać pod uwagę potrzeby otoczenia, w którym się znajdują, a z uwagi na bezpośredni kontakt z klientem część strategii firmy, którą jest marketing, powinna być planowana w sposób szczególnie odpowiedzialny.

Poniższa praca przedstawia wykorzystanie marketingu w sposób odpowiedzialny, zgodny z koncepcją społecznej odpowiedzialności przedsiębiorstw. Prezentuje również przykłady aktywności w obszarze marketingu społecznie zaangażowanego oraz kontrowersje z nimi związane. Celem pracy jest przedstawienie znaczenia marketingu społecznie odpowiedzialnego i jego wpływu na przedsiębiorstwa i społeczeństwo. Aby go zrealizować, dokonano analizy i oceny działań w obszarze marketingu społecznie zaangażowanego w praktyce, na wybranych przykładach.

\section{Pojęcie i istota marketingu}

Marketing to bardzo szerokie zagadnienie, uwzględnia wiele pojęć i narzędzi. Według Philipa Kotlera ${ }^{1}$ można wyróżnić dwie definicje marketingu: społeczną i dyrektorską. Określenia te przedstawiają marketing z różnych punktów widzenia. Społeczne ujęcie marketingu opisuje go jako proces społeczny, poprzez który jednostki uzyskują to, czego potrzebują. Proces ten odbywa się poprzez kreowanie, oferowanie oraz swobodną wymianę produktów i usług. Zaś dyrektorska definicja marketingu nazywa go sztuką sprzedawania produktów. Marketing traktowany jest przede wszystkim jako proces polegający na planowaniu i realizacji pomysłów, ustalaniu cen, a także promocji i dystrybucji idei, towarów oraz usług, tak by kreować wymianę realizującą cele przedsiębiorstw i jednostek ${ }^{2}$.

Realizacja dobrej strategii marketingowej opiera się przede wszystkim na kombinacji różnych form aktywności oraz doborze odpowiednich środków

\footnotetext{
${ }^{1}$ P. Kotler, Marketing, Dom Wydawniczy Rebis, Poznań 2015, s. 8.

2 Ibidem, s. 9.
} 
działania. Zawierają się one w koncepcji marketing mix (4P), uwzględniającej cztery podstawowe elementy oddziaływania na rynek. Do składowych tych należą ${ }^{3}$ :

- produkt (ang. product) - asortyment, jakość, opakowanie, marka, czyli wszystkie cechy produktu istotne z punktu widzenia konsumenta; w skład tego elementu marketing mixu wchodzą działania wspierające produkt, takie jak gwarancja czy pomoc techniczna;

- cena (ang. price) - polityka cenowa, m.in. rabaty, warunki płatności;

- miejsce, dystrybucja (ang. place) - kanały dystrybucji danego produktu, także rozwiązania logistyczne czy wygoda nabycia produktu;

- promocja (ang. promotion) - wszystkie działania komunikacyjne i promocyjne firmy, np. reklama.

Marketing służy realizacji celów przedsiębiorstw i przez efektywne funkcjonowanie spełnia wiele funkcji. Podstawową rolą marketingu jest gromadzenie i przekazywanie informacji rynkowej. Poza tym pełni on również funkcję edukacyjną i społeczną. Marketing ukierunkowany na nabywcę przynosi mu szczególne korzyści, takie jak: szeroki wybór asortymentu, konkurencyjna cena oraz jakość, profity związane z akcjami promocyjnymi, np.: degustacja, niższe ceny, a także wysoki standard obsługi oraz bogaty wybór źródeł informacji dotyczących oferty. Mimo tak wielu korzyści, jakie odnosi konsument, nie można pominąć negatywnych skutków stosowania zabiegów marketingowych. Na klientów w sposób ujemny wpływają takie zjawiska, jak: tworzenie przez firmy pozornie nowych produktów oraz przyspieszanie zużycia wyrobów trwałego użytku, przesadne różnicowanie produktów czy też zbyt intensywna i agresywna reklama ${ }^{4}$.

Powszechne spojrzenie na marketing zakłada, że jego celem jest taki wpływ na konsumenta, by nabył on produkt, bez uwzględniania swoich realnych potrzeb. Współczesna interpretacja pokazuje szersze spojrzenie na marketing, przede wszystkim skupia uwagę firmy na kliencie. Do takich celów należą w szczególnościs:

- określanie i zaspokajanie potrzeb konsumentów - rozpoznanie potrzeb, poznanie klienta, stworzenie odpowiedniego produktu lub usługi;

- budowanie dobrych relacji z konsumentami - dbanie o dobry wizerunek firmy i zdobywanie lojalności klientów;

- pobudzanie i utrzymywanie potrzeb wśród konsumentów - kreowanie popytu, w szczególności związanego z wejściem nowego produktu na rynek;

- zachęcanie i przyciąganie nowych konsumentów związane z oferowaniem produktów o określonych cechach pożądanych przez klientów.

${ }^{3}$ D. Filar, Współczesny marketing. Skuteczna komunikacja i promocja. Podręcznik dla studentów specjalności komunikacja urzędowa i biznesowa, UMCS, Lublin 2012, s. 22.

${ }^{4}$ Ibidem, s. 21.

${ }^{5}$ Cele marketingu, https://mfiles.pl/pl/index.php/Cele_marketingu (dostęp: 31.07.2016). 
Wobec wyżej wymienionych celów marketingu istotnym pojęciem wydaje się termin public relations (PR). Są to działania firmy mające na celu budowanie i utrzymywanie relacji przedsiębiorstwa z jej otoczeniem. PR to narzędzie komunikacyjne służące do kreowania pozytywnego wizerunku firmy oraz system reakcji na nieprzychylne informacje i niekorzystne zjawiska występujące w firmie $^{6}$. Public relations to relacje ze społeczeństwem - bardzo często traktowane są jako dodatek do marketingu, a także piąty element marketing mix (produkt, cena, dystrybucja, promocja). Jednocześnie uznaje się PR za trwałą funkcję zarządzania, wpływającą na pozyskiwanie i utrzymywanie przychylności obecnych oraz przyszłych zainteresowanych firmą, tak by jak najlepiej dopasować cele firmy do oczekiwań tych osób ${ }^{7}$.

\section{Rola i znaczenie zrównoważonego rozwoju i społecznej odpowiedzialności biznesu}

W czasach szybkiego rozwoju gospodarczego oraz nadmiernego wykorzystywania zasobów naturalnych ogromnego znaczenia nabiera koncepcja zrównoważonego rozwoju. Wyznacza ona granice zrównoważonego wzrostu zachowującego w równowadze potrzeby gospodarcze, społeczne i środowiskowe, ze szczególnym uwzględnieniem potrzeb przyszłych pokoleń. Jedna z podstawowych definicji zrównoważonego rozwoju określa go jako ,,proces zmian, w którym eksploatacja zasobów, kierunki inwestowania, kierunki postępu technicznego i zmiany instytucjonalne pozostają w harmonii i zachowują bieżąco i na przyszłość możliwości zaspokojenia ludzkich potrzeb i aspiracji" ". Zrównoważony rozwój można nazwać nowoczesną strategią rozwoju społeczno-gospodarczego, a przede wszystkim podstawą do odpowiedzialnego prowadzenia biznesu we współczesnym świecie. Założenia i zasady tak określonego wzrostu stają się szczególnie istotne w świetle wzrostu świadomości społeczeństwa oraz zwiększających się zagrożeń społeczno-środowiskowych. Problemy i potrzeby te stawiają przede wszystkim ogromne wyzwanie dla świata biznesu.

Bardzo mocno związana z ideą zrównoważonego rozwoju jest koncepcja społecznej odpowiedzialności biznesu (ang. corporate social responsibility - CSR). Według najnowszej definicji określania jest jako „odpowiedzialność przedsiębiorstw za ich wpływ na społeczeństwo". Oznacza to przede wszystkim,

${ }^{6}$ Stownik finansowy, www.findict.pl/slownik/public-relations-pr (dostęp: 30.07.2016).

${ }^{7}$ A. Frączek, Public relations jako narzędzie komunikacji społecznej, „Studia Gdańskie. Wizje i Rzeczywistość" 2011, t. 8, s. 117.

${ }^{8}$ Nasza wspólna przyszłość. Raport Światowej Komisji do Spraw Środowiska i Rozwoju, tłum. U. Grzelońska, E. Kolanowska, PWE, Warszawa 1991, s. 71.

${ }^{9}$ Komisja Europejska, Odnowiona strategia UE na lata 2011-2014 dotycząca społecznej odpowiedzialności przedsiębiorstw, $\operatorname{KOM(2011)~681,~wersja~ostateczna,~Bruksela~2011,~s.~} 7$. 
że firmy powinny być odpowiedzialne za swoje działania i decyzje podejmowane w danym otoczeniu - społeczeństwie, społeczności lokalnej, środowisku naturalnym. Społeczna odpowiedzialność biznesu powinna być wdrażana na każdym szczeblu funkcjonowania przedsiębiorstwa, obejmuje przede wszystkim obszary takie, jak ${ }^{10}$ :

- zaangażowanie społeczne i rozwój społeczności lokalnej - prowadzenie dialogu społecznego oraz włączenie organizacji społecznych i społeczności lokalnych w proces planowania i realizacji projektów, w szczególności dotyczących inwestycji społecznych;

- prawa człowieka - poszanowanie godności każdego człowieka, przeciwdziałanie dyskryminacji, ochrona praw pracowniczych;

- uczciwe praktyki operacyjne - etyczna działalność w stosunku do innych podmiotów, przeciwdziałanie korupcji oraz dbałość o uczciwą konkurencję;

- środowisko naturalne - zmniejszanie negatywnego wpływu firmy na otoczenie przyrodnicze, zmniejszanie emisji zanieczyszczeń, ograniczanie wykorzystywania zasobów naturalnych i energii oraz wszelkie działania proekologiczne;

- praktyki w miejscu pracy - zapewnianie dobrych warunków pracy, dbałość o rozwój i potrzeby pracowników;

- sprawy konsumenckie - utrzymywanie relacji z klientami oraz uczciwa i przejrzysta polityka marketingowa, edukacja rynku, rzetelna informacja na temat oferowanych produktów i usług, ich wpływu na zdrowie i bezpieczeństwo klienta;

- ład organizacyjny - efektywne zarządzanie firmą.

Warto zaznaczyć, że koncepcja CSR kładzie nacisk na sprawiedliwe traktowanie klientów, informowanie w sposób rzetelny o produktach i usługach, edukację konsumentów, a także uczciwą politykę marketingową. Oznacza to, że prowadzenie strategii marketingowej w firmie przyczynia się w szczególny sposób do odpowiedzialności danego przedsiębiorstwa za otoczenie, w którym się znajduje i działa. Warto dodać, że odpowiedzialny marketing przynosi nie tylko korzyści dla konsumenta, ale przede wszystkim przyczynia się do budowania pozytywnego wizerunku firmy i dodatnio przekłada się na jej wynik finansowy. Najlepszym rozwiązaniem jest implementacja odpowiedzialnego marketingu $\mathrm{w}$ firmie poprzez połączenie go z ideą CSR oraz dobrze zaplanowaną strategią PR.

\section{Odpowiedzialny marketing}

Wielu ekspertów uważa, że postrzeganie marketingu w takim sam sposób jak dotąd jest nieodpowiednie we współczesnym świecie. W czasach degradacji środowiska przyrodniczego, zmniejszania się zasobów surowców naturalnych,

${ }^{10}$ Social responsibility: 7 core subjects, www.iso.org/iso/sr_7_core_subjects.pdf (dostęp: 31.07.2016). 
a także eksplozji demograficznej oraz biedy i ubóstwa może się wydawać, że koncepcja marketingu staje na przeszkodzie budowaniu trwałego dobrobytu społeczeństwa ${ }^{11}$. W związku z takim podejściem pojawia się wiele pojęć uwzględniających w szczególny sposób potrzeby społeczeństwa i wymagania środowiska naturalnego. Jednym z nich jest wspomniana powyżej społeczna odpowiedzialność biznesu. Łącząc te koncepcje, można zatem mówić o marketingu odpowiedzialnym, humanitarnym, ekologicznym czy społecznym. Idea marketingu społecznego zakłada określenie oraz zaspokojenie potrzeb i interesów rynków w sposób konkurencyjny i wydajny, przy jednoczesnym zwiększaniu dobrobytu społeczeństwa. Idea ta zakłada wdrożenie do praktyki marketingowej zasad etycznych i społecznych, tak by równoważyć cele, takie jak: powiększanie zysku firmy, spełnianie oczekiwań klienta oraz dbałość o interes społeczny ${ }^{12}$.

Coraz częściej mówi się o marketingu społecznie zaangażowanym czy też cause related marketing (CRM). Pojęcia te definiuje się jako połączenie celów ekonomicznych firmy z celami społecznymi w ramach danej akcji, a konkretniej nazywa się je metodą służącą tworzeniu programów opartych na potrzebach przedsiębiorstwa, z jednoczesnym rozwiązywaniem problemów społecznych ${ }^{13}$. Oczywistym celem świata biznesu jest maksymalizacja zysków poprzez pogłębianie relacji z klientami. Jednocześnie istnieje wiele organizacji pozarządowych, które dążą do realizacji celów społecznych. Jednak wsparcie od państwa, które otrzymują, nie zawsze jest wystarczające. Wobec tego muszą one szukać innych źródeł pomocy i dotacji. Perfekcyjnym rozwiązaniem wydaje się marketing społecznie zaangażowany. W ten sposób przedsiębiorstwa mogą poprawiać swój wizerunek, budować zaufanie i trwałe relacje z konsumentami. Tym samym organizacje non-profit są w stanie gromadzić fundusze na przeprowadzanie akcji wspierających potrzeby społeczeństwa. Takie działania pozwalają na osiągnięcie wyniku win-win.

Korzeni CRM można doszukiwać się na początku lat 80. XX wieku w Stanach Zjednoczonych. American Express wprowadził akcję, podczas której przy każdej transakcji przy użyciu karty firma przekazywała jednego centa na projekt renowacji Statui Wolności. Podczas akcji zaobserwowano wzrost liczby transakcji kartą o $28 \%$, a także wzrost liczby jej użytkowników o $17 \%{ }^{14}$. Dane te pokazują, że akcja przyniosła korzyści samej firmie, a także przyczyniła się w pozytywny sposób do odnowy zabytku o dużym znaczeniu dla społeczeństwa.

Marketing społecznie zaangażowany definiowany jest jako działania komercyjne prowadzone przez przedsiębiorstwa, które wykorzystują techniki, pieniądze

${ }^{11}$ P. Kotler, Marketing, s. 26.

12 Ibidem.

${ }^{13}$ Encyklopedia CSR, https://odpowiedzialnybiznes.pl/hasla-encyklopedii/marketing-spolecznie-zaangazowany/ (dostęp: 31.07.2016).

${ }^{14}$ Cause Related Marketing: wprowadzenie i definicje, http://marketingspoleczny.pl/artykul. php?id_artykul=261 (dostęp: 31.07.2016). 
oraz strategie marketingowe po to, by wspierać ważne społecznie sprawy, a tym samym umacniać własny biznes. Poprzez takie przedsięwzięcia kreuje się pozytywny wizerunek firmy oraz jednocześnie zwraca się uwagę na problem społeczny, wspierając go i powodując wzrost funduszy przeznaczanych na dany $\operatorname{cel}^{15}$.

Marketing społecznie zaangażowany przynosi bardzo wiele korzyści zarówno dla społeczeństwa, jak i przedsiębiorstwa. Do pozytywnych skutków wdrażania CRM po stronie firm należą przede wszystkim: wzrost lojalności klientów, polepszenie reputacji i wizerunku społecznego, zwiększenie sprzedaży, a także wzrost wrażliwości społecznej pracowników oraz większa motywacja. Do korzyści społecznych można zaliczyć przede wszystkim: większy poziom zaangażowania w realizację celów społecznych, efektywną realizację celów statutowych organizacji non-profit, a także poprawę wizerunku społecznego organizacji, co może przekładać się na większe możliwości zaangażowania w inne programy ${ }^{16}$.

Podsumowując, marketing społecznie zaangażowany wspiera określony cel społeczny, tym samym przyczyniając się do poprawy sytuacji rynkowej i wizerunku firmy, która go wdraża. Warto jednak zaznaczyć, że o powodzeniu takich działań decyduje konieczna współpraca biznesu, organizacji społecznych oraz konsumentów.

\section{Marketing społecznie zaangażowany w praktyce}

Można przytoczyć bardzo wiele przykładów działalności firm w obszarze marketingu społecznie zaangażowanego. Jednym z najstarszych jest akcja firmy Austin Motor Company, która w 1942 roku przekazywała darowiznę na rzecz Royal National Lifeboat Institution. Każdy sprzedany przez firmę silnik do statku bądź łodzi oznaczał dodatkowe fundusze kierowane na realizację celów działalności instytucji ${ }^{17}$. Taka forma marketingu społecznie zaangażowanego jest najczęściej spotykaną i wydaje się najprostszą do wdrożenia z perspektywy firmy.

Do współczesnych przykładów CRM można zaliczyć takie akcje podejmowane przez przedsiębiorstwa, jak np. program „Podziel się posiłkiem” prowadzony przez firmę Danone. Głównym celem tego programu jest walka z niedożywieniem wśród dzieci. Akcja opiera się na zbiórce środków na sponsorowanie ciepłych posiłków dla dzieci w szkołach. Jej inicjatorem jest Danone, zaś bezpośrednim organizatorem zbiórki żywności zajmuje się Federacja Polskich Banków

${ }_{15}$ Wiedza-definicje. Cause Related Marketing, www.kampaniespoleczne.pl/wiedza_ definicje,2393,cause_related_marketing (dostęp: 31.07.2016).

${ }^{16}$ Encyklopedia CSR, https://odpowiedzialnybiznes.pl/hasla-encyklopedii/marketing-spolecznie-zaangazowany/ (dostęp: 31.07.2016).

${ }^{17}$ Cause Related Marketing: wprowadzenie i definicje, http://marketingspoleczny.pl/artykul. php?id_artykul=261 (dostęp: 1.08.2016). 
Żywności ${ }^{18}$. Zbiórka odbywa się w największych sklepach w całej Polsce, corocznie od 2003 roku, w ostatni weekend września. Zgromadzone produkty są dostarczane bezpośrednio organizacjom i instytucjom, takim jak: szkoły, domy dziecka, świetlice czy inne jednostki pomagające dzieciom i młodzieży.

Poza głównym celem programu, jakim jest przekazanie żywności najbardziej potrzebującym dzieciom w Polsce, zwraca się również szczególną uwagę na podnoszenie świadomości społeczeństwa w zakresie walki z niedożywieniem, przede wszystkim wśród dzieci, a także kładzie się nacisk na edukację oraz aktywizację organizacji czy też lokalnych liderów do podejmowania samodzielnych działań na rzecz rozwiązania problemu niedożywienia ${ }^{19}$.

Firma Danone, poza tym, że jest inicjatorem akcji, podejmuje również inne konkretne działania w tym obszarze. Prowadzi np. sprzedaż produktów oznakowanych w specjalny sposób - część zysku pochodząca z ich sprzedaży przekazywana jest właśnie na walkę z niedożywieniem. Ponadto firma prowadzi program grantowy „Masz pomysł? Podziel się Posiłkiem!”, którego celem jest wsparcie w postaci dotacji dla lokalnych organizacji zajmujących się realizacją projektów mających na celu edukację żywieniową oraz wsparcie rozwoju psychicznego i fizycznego ${ }^{20}$.

Jako inne przykłady wdrażania idei marketingu społecznie zaangażowanego można podać kampanie edukacyjno-promocyjne organizowane przez różne firmy. Jedną z takich jest akcja firmy Frosta „Może zadbajmy o morze”, współorganizowana z pozarządową organizacją Marine Stewardship Council Polska (MSC Polska). Kampania ta ma na celu edukację w zakresie świadomego wyboru konsumowanych ryb. W ten sposób firma zwraca uwagę na problem środowiskowy, jakim jest niewystarczająca ochrona ekosystemu morskiego, a także nadmierna eksploatacja łowisk oraz nieodpowiedzialne praktyki rybackie. W ramach akcji uświadamia się odbiorców na temat stanu mórz czy też gatunków zagrożonych ryb. Ponadto Frosta, jako firma sprzedająca produkty rybne, do swojej produkcji wykorzystuje ryby pochodzące z certyfikowanych łowisk. Na opakowaniach produktów można znaleźć certyfikaty MSC, świadczące o pozyskiwaniu ryb według zrównoważonych standardów ${ }^{21}$.

Poza wyżej wymienionymi przykładami istnieje bardzo wiele innych akcji, programów czy też kampanii prowadzonych przez przedsiębiorstwa w zakresie CRM. Większość z nich często stanowi również część strategii CSR w firmie, a informacje o nich można znaleźć na stronach internetowych firm w zakładkach

${ }^{18}$ Podziel się posiłkiem, http://podzielsieposilkiem.pl/ (dostęp: 1.08.2016).

19 Podziel się posiłkiem - Banki żywności, www.bankizywnosci.pl/pl/projekty/podziel-sie-posilkiem.html (dostęp: 1.08.2016).

${ }^{20}$ Danone - Podziel się positkiem, www.danone.pl/Spoleczna-odpowiedzialnosc/Spoleczenstwo/Podziel-sie-Posilkiem (dostęp: 1.08.2016).

${ }^{21}$ Frosta zachęca do dbania o morze, www.kampaniespoleczne.pl/csrcrm,7340,frosta_zacheca_do_dbania_o_morze (dostęp: 3.08.2016). 
związanych właśnie ze społeczną odpowiedzialnością biznesu. Przykłady działań w obszarze marketingu społecznie zaangażowanego wyraźnie pokazują ich zależność od idei CSR oraz wspólne obszary aktywności.

\section{Kontrowersje związane z marketingiem zaangażowanym społecznie}

Tak samo, jak istnieje bardzo wiele pozytywnych przykładów działalności w obszarze CRM, tak również można dopatrzeć się licznych przykładów działań wykorzystywania go w sposób niewłaściwy lub kontrowersyjny. Dla przeciwników i krytyków marketingu bardzo często połączenie go z aspektami społeczno-środowiskowymi to tylko tzw. przykrywka dla realnego celu działań, jakim jest manipulacja klientem, tak by zakupił on produkt, który oferuje mu firma.

Jedną z firm, która prowadzi kampanie marketingowe mające za zadanie zwrócić uwagę na problemy społeczne, a jednocześnie wywołujące wśród wielu odbiorców pewne kontrowersje jest firma Adrian, zajmująca się produkcją rajstop. Jedną z najbardziej kontrowersyjnych akcji zorganizowanych przez firmę jest kampania reklamowa z 2015 roku. W wielu polskich miastach, m.in. w Poznaniu, Gdańsku czy Łodzi, pojawiły się billboardy, które przedstawiały kobietę w czarnych pończochach opartą o nagrobek cmentarny. Kolorystyka plakatu została utrzymana w czarno-białych odcieniach, zaś powagę zdjęcia podkreślał cytat z wiersza ks. Jana Twardowskiego: „Spieszmy się kochać ludzi tak szybko odchodzą" umieszczony tuż pod sloganem firmy: „Adrian kocha wszystkie kobiety". Warto zaznaczyć, że billboardy pojawiły się na ulicach miast jesienią, w czasie zbliżającego się w Polsce święta zmarłych.

Kampania spotkała się z dużą kontrowersją oraz krytyką ze strony konsumentów, a także mediów. Komentowało ją wiele osób, w szczególności eksperci i specjaliści w dziedzinie marketingu, komunikacji czy też etyki w biznesie. Poruszenie nastąpiło również wśród internautów na portalach społecznościowych. W wypowiedziach można było znaleźć komentarze opisujące kampanię jako „,niesmaczną”, „bez klasy” czy też „,mało inteligentną”. Zarzucano również autorom brak realnego powiązania produktu z wykorzystanym w reklamie cytatem ks. Twardowskiego 22 .

Autorzy reklamy podkreślali wymiar społeczny kampanii oraz istotę problemu, którego istnienie chcieli zaznaczyć, zostawiając z boku swój produkt. „Nie reklamuję rajstop. Starałam się powiedzieć, że życie biegnie nieubłaganie. Że gonimy często za rzeczami, które z pewnej perspektywy nie mają najmniejszego

${ }^{22}$ Reklama rajstop Adrian z grobem i cytatem ks. Twardowskiego. „Pokazujemy, że życie biegnie nieublaganie", www.wirtualnemedia.pl/artykuł/reklama-rajstop-adrian-z-grobem-i-cytatem-z-ks-twardowskiego-pokazujemy-że-życie-biegnie-nieubłaganie (dostęp: 12.08.2016). 
znaczenia. Że jesteśmy dla siebie niemili i nietolerancyjni”23 - tak całą kampanię komentowała właścicielka firmy i inicjatorka akcji promocyjnej.

W innych edycjach kampanii reklamowych firmy Adrian używano także wizerunków osób oraz haseł takich, jak: „Każdy ma prawo być sobą” - zdanie z plakatu z Anną Grodzką, „Uzależniona, nie znaczy gorsza” - hasło z kampanii przeprowadzonej wraz z Iloną Felicjańską, wicemiss Polonia w 1993 roku, która doświadczyła problemów alkoholowych, czy „Uwierz! Rak. To się leczy” - slogan $\mathrm{z}$ billboardu przedstawiającego kobietę po mastektomii.

Wyżej opisane podejście do kampanii marketingowej mimo wszystko zwraca uwagę na problemy i kwestie ważne społecznie. Jednak finalnie wydaje się, że sposób, w jaki przeprowadzono kampanie, ma bardziej na celu zwrócenie uwagi na firmę niż na sam problem społeczny. Poprzez takie zabiegi marketingowe konsument przede wszystkim zapamiętuje nazwę marki, ponieważ było o niej głośno, a nie zawsze realnie zwraca uwagę na problem, który został poruszony. Kontrowersyjność takiej kampanii polega na wykorzystaniu w prowokacyjny sposób kwestii wrażliwych społecznie, w celu uzyskania rozgłosu i zainteresowania firmą.

\section{Podsumowanie}

Zmiany zachodzące w życiu społeczno-gospodarczym sprawiają, że reorientacji ulegają również cele biznesowe. Obecnie, poza maksymalizacją zysku, zwraca się również szczególną uwagę na potrzeby społeczne. Jedną z form wdrażania nowych priorytetów stał się marketing społecznie zaangażowany. Działania w jego obszarze są ściśle zintegrowane z ideą i zasadami społecznej odpowiedzialności biznesu. Przykłady społecznych kampanii marketingowych pokazują, jaki potencjał ma zaangażowanie biznesu w sprawy i problemy społeczeństwa. Istnieją także przykłady, które są dowodem na to, iż aktywizacja biznesu na tle społecznym powinna być przemyślana i wyważona. Zbyt agresywne uwypuklenie spraw wrażliwych społecznie może mieć negatywny wpływ na firmę. Przedsiębiorstwa chcące wprowadzać społeczne działania marketingowe powinny skupiać się przede wszystkim na realnym problemie społecznym, zaś korzyści wizerunkowe i ekonomiczne należy traktować jako wartość dodaną, a nie główny cel działania. Analiza wybranych przykładów działań w obszarze marketingu społecznie zaangażowanego pokazuje wiele korzyści dla przedsiębiorstw, ale także i zagrożeń, które mogą wynikać z nieodpowiedniego dostosowania kampanii marketingowej do odbiorców. 


\section{Bibliografia}

Bakalarska J., Marketing wartości, Wydawnictwo Słowa i Myśli, Lublin 2016.

Baran G., Marketing wspóttworzenia wartości z klientem. Społecznotwórcza rola marketingu w procesie strukturacji interakcyjnego środowiska doświadczeń, Instytut Spraw Publicznych Uniwersytetu Jagiellońskiego, Kraków 2013.

Cause Related Marketing: wprowadzenie i definicje, http://marketingspoleczny.pl/artykul.php?id_ artykul=261 (dostęp: 31.07.2016).

Cele marketingu, https://mfiles.pl/p1/index.php/Cele_marketingu (dostęp: 31.07.2016).

Danone - Podziel się posiłkiem, www.danone.pl/Spoleczna-odpowiedzialnosc/Spoleczenstwo/Podziel-sie-Posilkiem (dostęp: 1.08.2016).

Encyklopedia CSR, https://odpowiedzialnybiznes.pl/hasla-encyklopedii/marketing-spolecznie-zaangazowany/ (dostęp: 31.07.2016).

Filar D., Wspótczesny marketing. Skuteczna komunikacja i promocja. Podręcznik dla studentów specjalności komunikacja urzędowa i biznesowa, Wydawnictwo UMCS, Lublin 2012.

Frączek A., Public relations jako narzędzie komunikacji społecznej, „Studia Gdańskie. Wizje i rzeczywistość" 2011, t. 8.

Frosta zachęca do dbania o morze, www.kampaniespoleczne.pl/csrcrm,7340,frosta_zacheca_do_ dbania_o_morze (dostęp: 3.08.2016).

Granice i zastosowania reklamy społecznej, red. M. Nóżka, K. Keller, Uniwersytet Jagielloński, Instytut Socjologii, Kraków 2007.

Komisja Europejska, Odnowiona strategia UE na lata 2011-2014 dotycząca społecznej odpowiedzialności przedsiębiorstw, KOM(2011) 681 wersja ostateczna, Bruksela 2011.

Kotler P., Marketing, Dom Wydawniczy Rebis, Poznań 2015.

Maćkowska R., Public relations: efektywne komunikowanie w teorii i praktyce, Wydawnictwo Akademii Ekonomicznej im. Karola Adamieckiego, Katowice 2010.

Marketing wartości społecznych, red. nauk. W. Domachowski, Wydawnictwo Naukowe UAM, Poznań 2003, Człowiek i spoleczeństwo, t. 21.

Nasza wspólna przyszłość. Raport Światowej Komisji do Spraw Środowiska i Rozwoju, thum. U. Grzelońska, E. Kolanowska, PWE, Warszawa 1991.

Podziel się positkiem, http://podzielsieposilkiem.pl/ (dostęp: 1.08.2016).

Podziel się posiłkiem - Banki żywności, www.bankizywnosci.pl/pl/projekty/podziel-sie-posilkiem. html (dostęp: 1.08.2016).

Reklama rajstop Adrian z grobem i cytatem ks. Twardowskiego. „Pokazujemy, że życie biegnie nieubłaganie", www.wirtualnemedia.pl/artykuł/reklama-rajstop-adrian-z-grobem-i-cytatem-z-ks-twardowskiego-pokazujemy-że-życie-biegnie-nieubłaganie (dostęp: 12.08.2016).

Stownik finansowy, www.findict.pl/slownik/public-relations-pr (dostęp: 31.07.2016).

Social responsibility: 7 core subjects, www.iso.org/iso/sr_7_core_subjects.pdf (dostęp: 31.07.2016).

Wiedza-definicje.CauseRelatedMarketing, www.kampaniespoleczne.pl/wiedza_definicje,2393,cause_ related_marketing.

\section{Streszczenie}

Marketing opisuje procesy społeczne polegające na swobodnej wymianie produktów i usług - nazywa się go również sztuką sprzedawania produktów. Przede wszystkim jest to proces oparty na planowaniu i realizacji pomysłów, ustalaniu cen, a także promocji i dystrybucji idei, towarów oraz usług. Wzrost znaczenia koncepcji zrównoważonego rozwoju i idei społecznej 
odpowiedzialności biznesu powoduje, że strategie marketingowe w firmach zaczynają bazować na odpowiedzialności i uczciwości. Tak postrzegana forma marketingu prowadzi do implementacji marketingu społecznie zaangażowanego. Polega on na łączeniu celów ekonomicznych firmy z celami społecznymi. Można znaleźć wiele pozytywnych przykładów takich akcji i działań prowadzonych przez przedsiębiorstwa i służących społeczeństwu. Niestety pojawiają się także kontrowersyjne przypadki, budzące często niesmak wśród konsumentów. Spowodowane są one niewłaściwym zrozumieniem idei oraz chęcią poprawy wizerunku firmy i zwrócenia uwagi na istnienie marki na rynku w agresywny sposób. Celem pracy jest przedstawienie zastosowania marketingu społecznie zaangażowanego z uwzględnieniem zasad społecznej odpowiedzialności biznesu, a także kontrowersji pojawiających się w tym obszarze.

Słowa kluczowe: marketing, marketing społecznie zaangażowany, społeczna odpowiedzialność biznesu 